\title{
Új kihívások az Európai Unió egészségügyi rendszerében
}

\section{New challenges for health systems of the European Union}

\author{
K. BORUZS ${ }^{1}$, G. BÁNYAI², K. BíRó ${ }^{3}$ \\ ${ }^{1}$ Debreceni Egyetem Népegészségügyi Kar Egészségügyi Menedzsment és Minőségirányítási Tanszék, \\ boruzs.klara@med.unideb.hu \\ 2 Debreceni Egyetem Népegészségügyi Kar Egészségügyi Menedzsment és Minőségirányítási Tanszék, \\ banyai@med.unideb.hu \\ ${ }^{3}$ Debreceni Egyetem Népegészségügyi Kar Egészségügyi Menedzsment és Minőségirányítási Tanszék, \\ kbiro@med.unideb.hu
}

Absztrakt. Az egészségügyi ágazat nem csak hazánkban, de Európa egészében is számos nehézséggel küzd. A 21. században a világot új, nagy horderejü problémák állítják komoly nehézségek elé, melyek jelentős kihatással vannak az egészségügyre is. Felvázoljuk napjaink kihívásait és megvizsgáljuk azok várható szakmapolitikai hatásait is.

Abstract. The health system is facing a number of difficultiesnot only in our country, but in the whole of Europe. In the 21st century never before seenlarge-scale problems pose a serious threat to our world, which have a significant impact on health care. We outline the challenges of today and examine their likely effect on coming health policies.

\section{Bevezetés}

Az elmúlt időszakban több olyan meghatározó esemény következett be, amely jobban meg fogja változtatni az egészségügy természetét, mint akármilyen eddigi kutatói felfedezés, amely az ágazatot érintette. A mai álláspontok szerint négy esemény, illetve folyamat az, amely kiemelkedően meghatározó befolyással, ráhatással lesz az Európai Unió egészének, illetve tagállamainak egészségügyi rendszerére. Elsőként említendő az 2008-ban kezdődőGazdasági Világválság, amelynek következményei az egészségügyre is hatással voltak és vannak. Ugyanilyen jelentős az a felismerés melyet már az USA és Kína is elismert -, hogy a klímaváltozás lesz a legnagyobb hatással a jövőben az egészségre és a jólétre. [12]A víz- és élelmiszerhiány pedig tovább súlyosbíthatja a klímaváltozás által okozott kihívást. További problémaként a jelenleg is zajló migrációs folyamat emelendő ki, mely komoly kihívások elé állítja egész Európát. Sokat hallunk az illegális bevándorlás kérdéséről és arról, hogy ez a jelenség milyen társadalmi, gazdasági problémákat jelent az Európai Unió egészének és tagállamainak egyaránt. Viszont keveset beszélünk arról, hogy ez a közelmúltban felfokozódó kérdés 
milyen mértékben befolyásolja az eddig elsősorban a fejlődő országokban szórványosan vagy tömegesen előforduló megbetegedések mentén a tagállamokban élők egészségi állapotát, valamint, hogy milyen mértékben növelheti meg Európa amúgy is túlterhelt egészségügyi rendszereire nehezedő nyomást. A negyedik jelenség az egészségügyi ágazat humánerőforrás problémájának megoldatlansága, mely inkább folyamatként tekinthető és jelentős kihívás elé állítja a már jelenleg is túlterhelt egészségügyi rendszer egészét.

Ezeknek a drámai eseményeknek a következményei további kihívások elé állítják az ágazatot Európában és tovább nehezítik a szükséglet és keresletnövekedésből, valamint a humán erőforrás hiányából adódó válságot az egészségügyben. Várható, hogy az új kihívások, melyekkel találkozunk, olyan problémákkal szembesítik az Európai Uniót, melyre jelenleg még nem rendelkezik megnyugtató megoldásokkal. Jelen írás célja a 21. századi új kihívások összegzése az Európai Unió szemszögéből, bemutatva a rendelkezésre álló információkat a már felvázolt kihívásokkal kapcsolatban. Az összegzés a hivatalos uniós dokumentumok, munkadokumentumok, háttéranyagok áttanulmányozásával került összeállításra, mely szakirodalmi áttekintés kiindulópontja lehet a „Health inAllPolicies” stratégiai cél megvalósításának (az „egészség szakpolitikai integrálására" irányuló megközelítés). Támpontot adhat a kihívások hátterében zajló folyamatok megértéséhez, valamint segíthet eligazodni az egymástól független, de egymásra is ható jelenségek között.

\section{Kihívások}

A 20. század egészségügyében a fő hangsúly a hatékonyságon és hatásosságon volt. Napjainkban jelentős változás szemtanúi lehetünk az ágazatban, hiszen a betegek, az eredmények és az értékek kerülnek előtérbe, mivel a kihívások, amellyel a 21. század egészségügye minden országban szembesülni kénytelen hatalmas és növekvő. [12] A 21. században korábban elképzelhetetlen módon növekedtek a költségek az egészségügyben, amelyeket csak tetéztek az említett, kihívást jelentő események. Alapvetően a növekedés több folyamat következménye volt, amelyben a keresleti oldalt szélesítette a születéskor várható átlagos élettartam növekedése, amely elöregedő társadalmakat eredményez [3], az ágazatban bekövetkező epidemiológiai paradigmaváltás [3], az ellátórendszerben egyre inkább fogyasztóként megjelenő beteg. Nem segítette a folyamatot az sem, hogy olyan problémák, amelyeknek kezelése korábban más ágazatban történt, csendesen belopóztak az egészségügybe az egészség holisztikus értelmezése következtében [1]. A kínálati oldalon az orvosi technológia robbanásszerű fejlődése eredményeként olyan innovatív termékek és eljárások jöttek létre, melyek jelentős költségigénnyel jelentek és jelennek meg az ágazatban [16]. Így az orvosi eljárások köre folyamatosan bővül, amely a defenzív etikai és orvosi etikai kérdések miatt további meghatározó igényeket generál.,,Versenyfutás kezdődött az orvostudomány által már megoldható, de gazdaságilag korlátokba ütköző egészségügyi ellátások között.” [2]

\subsection{Gazdasági Világválság}

Az egyik kihívást a Gazdasági Világválság generálta, mely az amúgy is „szűkösnek” ítélt egészségügyi ráfordítások lehetőségeit tovább korlátozta számos országban. 
A fentiek eredőjeként nem meglepő, hogy nagyon sok országban próbálják visszafogni az egészségügyi kiadásokat, de vannak olyan államok, ahol a GDP-hez viszonyított korábbi mérték szerényebb volt az OECD országok átlagához képest, vagy az egészséget egy jó befektetésnek tekintették, így ez a törekvés nem jelent meg reális célként az elmúlt időszak gazdasági nehézségei ellenére sem.

Az OECD 2015 nyarán publikált felméréséből egyértelműen kiderül (1. ábra), hogy csak hat országban - Magyarország, Mexikó, Svájc, Israel, Japán és Chile - volt az egészségügyre fordított kiadás a válság alattés után magasabb, mint 2009 előtt [11], azonban ezt a változást csak a 2005-2009 évek között lezajlott trenddel összehasonlítva lehet teljes egészében értékelni.

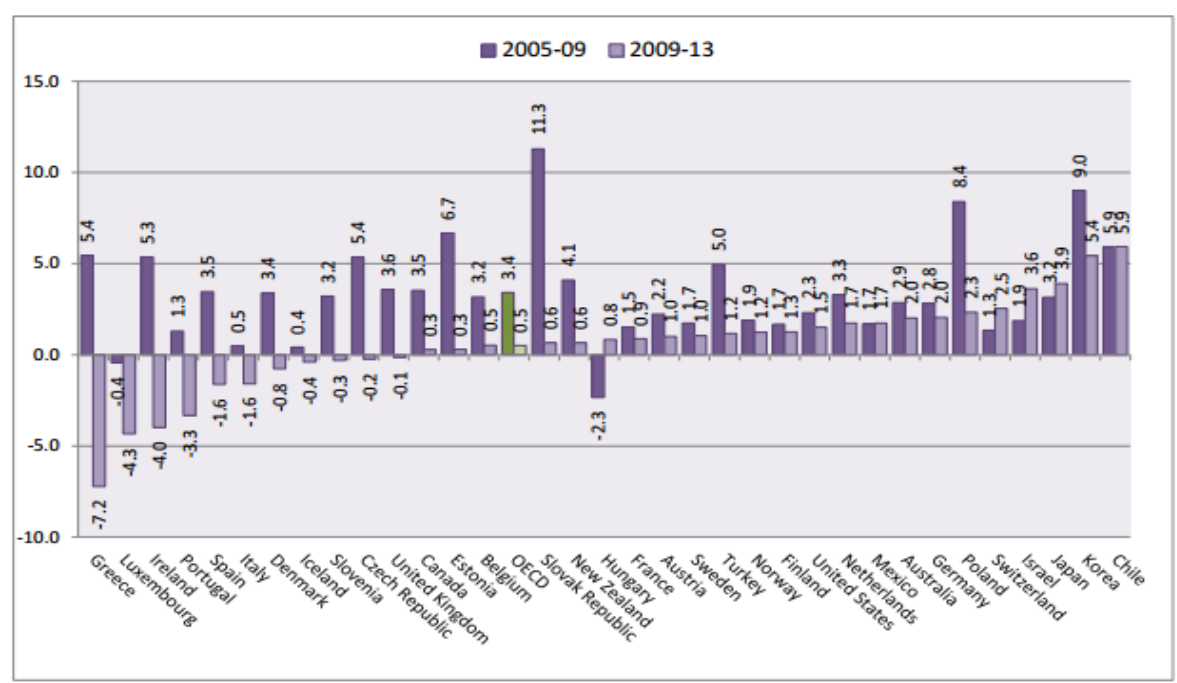

1. ábra: Az átlagos éves növekedés az egy före jutó egészségügyi kiadások reálértékén, az OECD-országokban, 20052013

(Forrás: FOCUS on Health Spending @ OECD Health Statistics, 2015)

A tanulmány rávilágít arra is, hogy az egészségügyi kiadások közel háromnegyede állami forrásból (akár a kormányzat vagy a társadalmi egészségbiztosítás) származik az OECD országaiban. A gazdasági válság előtt kifejezett volt a növekedés az állami egészségügyi kiadások tekintetében, éves szinten közel 4\% (2. ábra). 2010-ben, ez a növekedés szinte megállt és azóta a kiadások növekedése igen lassú volt.

A lakossági kiadásoknak a növekedése is csökkent 2009 óta, de ez a csökkenés kevésbé volt hangsúlyos,mint az állami szektorban az OECD tagországaiban. Az Out-of-pocket kiadások tovább nőttek 2009 óta, bár lassabb ütemben (mértéke 1,0\% körüli évente átlagosan), amely részben a költségmegosztásra vonatkozóan bevezetett intézkedések hatása számos országban.

Sok országban a magán egészségbiztosítások csak marginális szerepet játszanak az ágazatban, míg más államokban azonban tekintélyes részét teszik ki az egészségügyi finanszírozásnak, így pl. az Amerikai Egyesült Államokban (35\%), Chile-ben (21\%). A magán egészségbiztosítások kiadásainak növekedése jelentősen lelassult a 2009-2011 közötti időszakban, azonban 3,2\% -kal nőttek a 2011 és 2013 közötti időszakban. [11] 


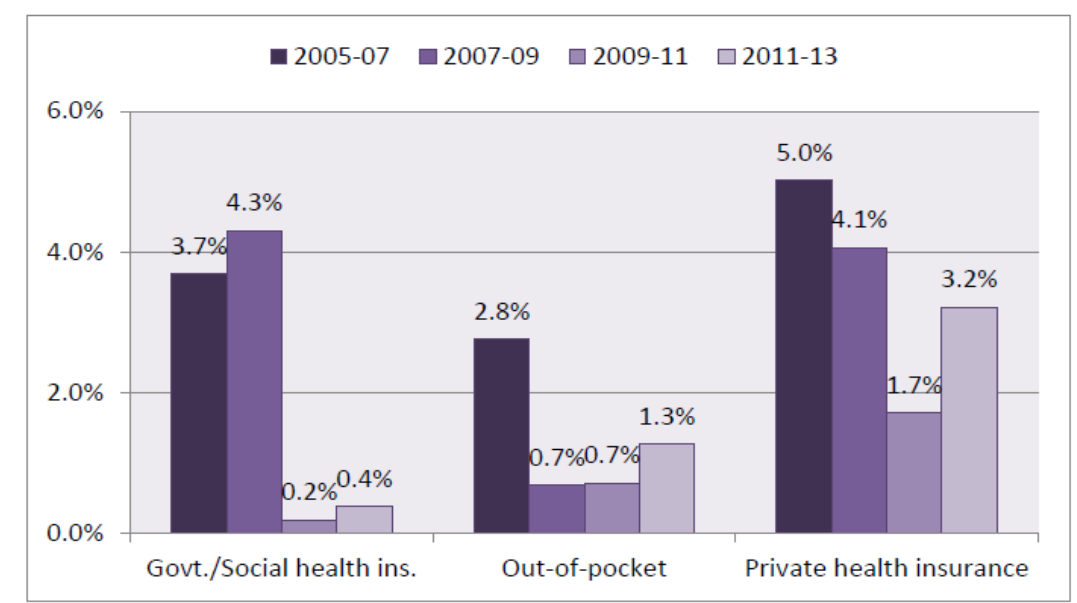

2. ábra: Az egy före jutó évi átlagos növekedési ütem az egészségügy finanszírozásában reálértéken, 2005-2013

(Forrás: FOCUS on Health Spending @ OECD Health Statistics 2015)

Mindamellett, hogy nem söpörhetjük félre a hatékonyságot az ágazatban, hiszen szűkösek a rendelkezésre álló források és van mit javítani a költséghatékonyságon belül a felhasználásra szánt keretek vonatkozásában is, ma már tudjuk azt is, hogy egyre nagyobb teret kell nyernie az egyéni felelősségnek és az öngondoskodó szemléletnek is saját egészségünk védelme érdekében. Így érthető, hogy a betegek prevencióra irányuló vagy „self-management”programjai egyre hangsúlyosabban jelennek meg az ágazatban, amely egyik eszköze lehet annak, hogy enyhíthessük a pénzügyi szűkösség okozta problémákat.

\subsection{Migráció}

Egy másik jelentős kihívást generál az ágazatban az új (vagy az elmúlt időszakban csak sporadikusan fellelhető) járványos megbetegedések megjelenése. Tovább súlyosbítják ezt a problémát az illegális bevándorlás illetve annak lehetséges hatásai.

A 21. század egészségügyének nem csak a 20. századból örökölt betegségekkel kell megküzdenie, de fel kell vennie a harcot az új betegségekkel is. Valójában néhány szegény ország ugyanakkor még mindig a 19. század egészségügyi problémáival küzd, úgy, mint a tuberkulózis vagy a kolera. Ugyanakkor a fejlődő országoknak meg kell birkózniuk olyan nem járványos egészségügyi problémákkal, melyek az életmód változás és az elöregedő társadalom hozadékai.

Az utóbbi évtizedekben a társadalom már a saját bőrén is érezhette az AIDS vagy a madárinfluenza veszélyeit, és azon evolúciós problémákat, melyek a társadalmi változások velejárói, és amelyek új epidemiológiai problémákat generáltak, mint például az anorexia nervosa. [18]

Mindezek mellett eddig csak sporadikusan megjelenő fertőző ágensek manifesztálódnak járványos méreteket öltve a világ bizonyos részein, gondoljunk csak napjainkban a Zika-vírus okozta megbetegedésre. A világban már több országban érvényes szükségállapotot rendeltek el a Zika-vírus terjedése miatt, de a kór megjelenését regisztrálták már Európában is. A WHO időben részletes tájékoztatást tett közzé honlapján a teendőkkel kapcsolatban. [20] 
Bár az Európára napjainkban jellemző migrációs probléma még nem manifesztálódott 2014-ben, de megvizsgálva a WHO-nak ebben az évben jelentett epidemiológiai megbetegedéseket(3. ábra) látható, hogy a „behurcolt” megbetegedések az adott évben milyen mértékűek voltak a világon és ezáltala szakembereknek lehetőségük van a valódi veszélysúlyának meghatározására, így ennek alapján közös stratégia és intézkedési terv kidolgozására. [19]

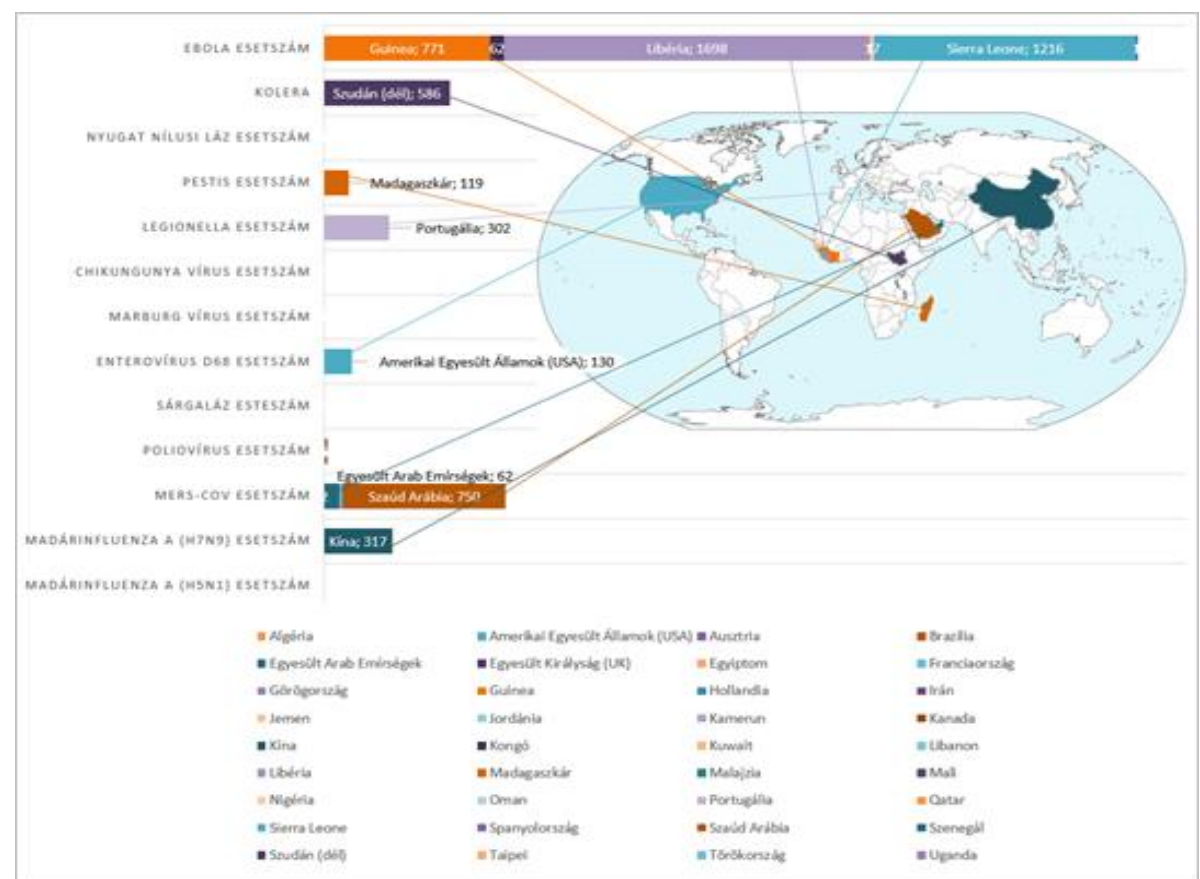

3. ábra: 2014-ben a WHO-nak jelentett epidemiológiai történések országonként - saját szerkesztés (Forrás: WHO, Emergenciespreparadness, response, 2014.)

PatrickBrzoska és munkatársai is ezt erősítik meg 2015-ben publikált kutatásukban, amelyben a migráció és az egészség, mint potenciális új nemzeti egészségügyi célpont témáját vizsgálták meg Németországban. A vizsgálat rámutatott arra, hogy az egységes kritériumok meghatározása a küzdelemben egy értékes eszköz lehet az egészségpolitika kialakításában. Leszögezik, hogy ez is hozzájárulhat ahhoz, hogy Európa közös célok meghatározásával kezelhesse az újonnan jelentkező kihívást. [5]

Alexander Kentikelenis és munkatársai 2015. évben publikált áttekintésükben megállapították, hogy a rendelkezésre álló információk arra utalnak, hogy egyes bevándorló csoportok rontják az egészségi kockázatokat, és hogy a költségvetési megszorítások az ágazatban egyértelműen korlátozzák az erre adható közegészségügyi válaszokat. [14]

\subsection{Klímaváltozás}

A korábban felvetett két komoly kihívás mellett kiemelt jelentőségúek a klímaváltozással összefüggésbe hozható egészségügyi problémák és az ebből fakadó betegellátást érintő terhelés az ágazat számára. 
Az Eurostat rendszeresen kimutatást készít [10], amelyben az összes mesterséges kibocsátást bemutatja a „Kiotó kosár” üvegházhatású gázaira vonatkozóan. A vizsgált évben az éves teljes kibocsátás változását értékelik 1990-hez viszonyítva (4. ábra). A 4. ábrán jól látható, hogy az üvegházhatású gázok kibocsátása 2013-ban Portugáliában, Spanyolországban, Izlandon és Cipruson nemhogy csökkent volna a bázis évhez viszonyítva (1990), hanem éppenséggel nőtt. A legnagyobb mértékű csökkenés elsősorban a századfordulót követően csatlakozott poszt-szocialista országokban figyelhető meg. Ez a pozitívnak tűnő változás viszont feltehetőleg nagyobb részben nem a környezetvédelmi intézkedéseknek, hanem a rendszerváltozást követő gazdasági változásoknak (pl. a termelés visszaesésének) tudható be. Valós, környezettudatos lépéseknek köszönhető kibocsátás csökkenés leginkább a „Tizenötök Európája” (EU-15) esetén tapasztalható (átlag: 84.88) még úgy is, hogy ebbe körbe tartozik a legrosszabban teljesítők között már említett Spanyolország és Portugália is.

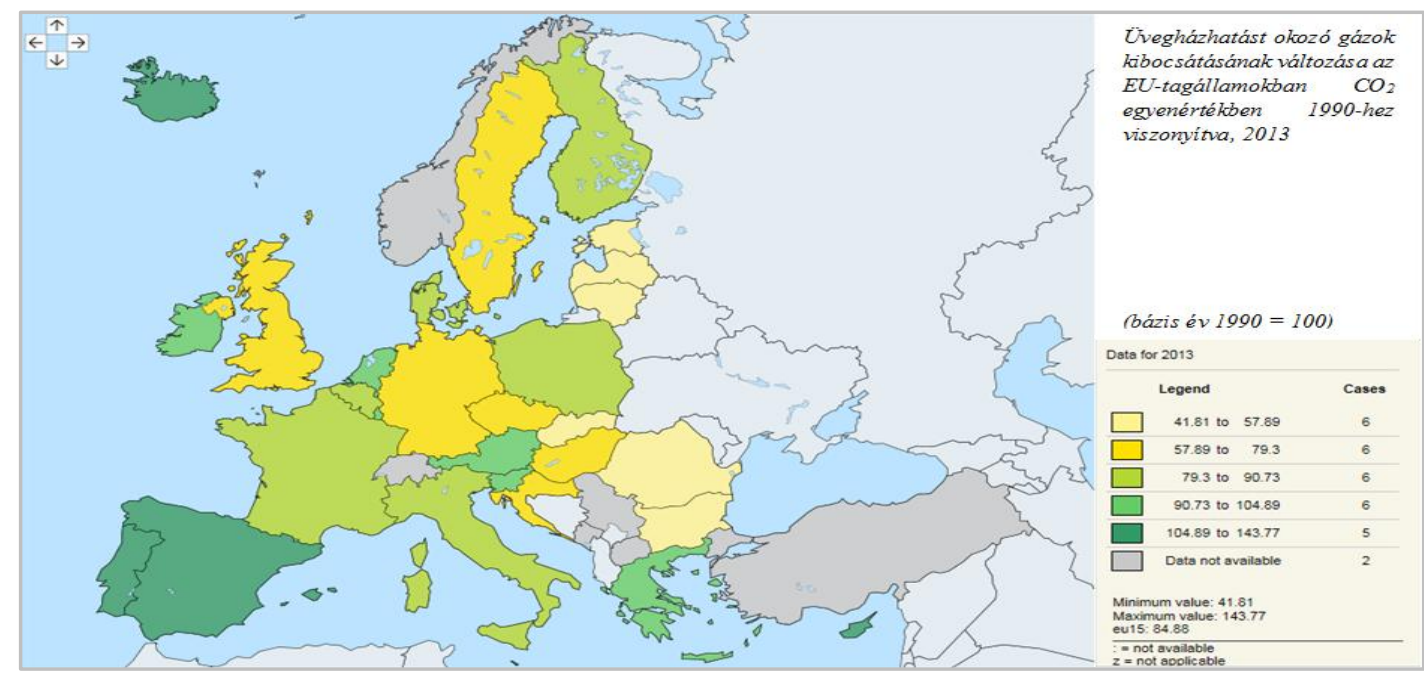

4. ábra: Az üvegházhatású gázok kibocsátásának alakulása

(Forrás: Eurostat)

Ennek jelentőségét jól példázza, ha meghatározzuk, hogy a klímaváltozás milyen mértékben hathat az emberi szervezetre, ezáltal pedig közvetett módon milyen mértékű kihívást jelent az egészségügyi rendszernek. A CDC (CentersforDiseaseControl and Prevention) által készített összefoglaló ábra (5. ábra) jól mutatja a klímaváltozáson belül az egyes klíma ágensekhez kötődő hatásokat az emberi szervezetre vonatkozóan. [6] 


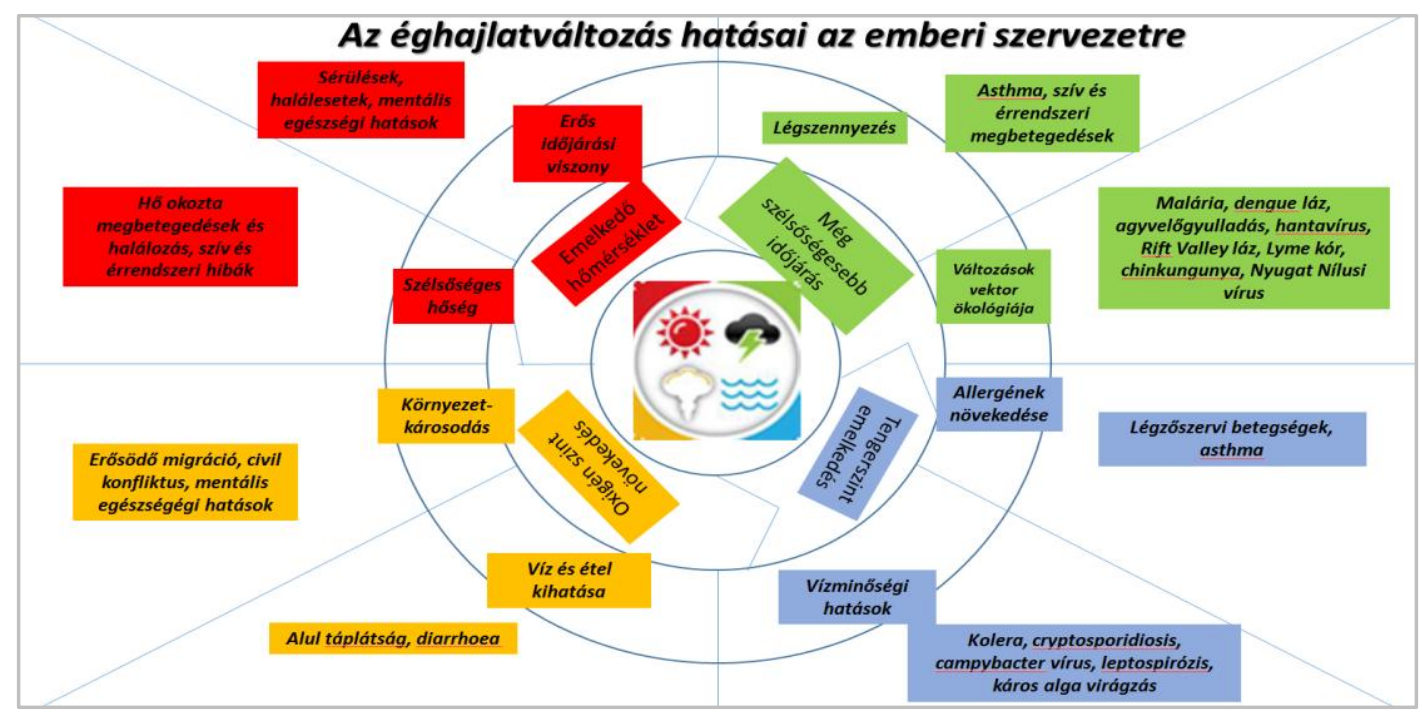

5. ábra: Klímaváltozás hatásai az emberi szervezetre

(Forrás:CentersforDiseaseControl and Prevention, National Center forEnvironmental Health, www.cdc.gov)

A felmelegedés hatását tekintve a hőmérséklet egyfokos emelkedése az európai országokban a halálozási ráta 1-4\%-os növekedésével jár. Lényegében a felmelegedéssel összefüggésben az élelmiszerek útján terjedő fertőzések növekedésével is számolni kell. Ezen betegségek előfordulási gyakoriságának emelkedése az elkövetkezendő időszakban többletterhet jelenthetnek a társadalom számára. A klímaváltozás kapcsán a vektorok (szúnyogok, kullancsok, stb.) által terjesztett betegségek kockázata is növekszik (az aktív időszak és a populáció növekedése miatt), valamint új betegségek megjelenésének a lehetőségeire is fel kell készülni a kontinentális Európa területén. A vektorok terjedéséhez hasonlóan a víz által terjesztett járványok kitörésének veszélye is emelkedik a bőséges csapadék miatt, ami mozgásba hozza a kórokozókat, illetve a szennyvízhálózat kiöntése révén vízfertőzést okozhat. Ezzel szemben a nyári vízhozamcsökkenés is veszélyekkel jár, mely növelheti a bakteriális és vegyi fertőzés rizikóját. Bár az európai légszennyezettségi adatok hosszú ideje javuló tendenciát mutatnak, a levegőszennyezés egészségügyi kockázatai a por és ózon okozta problémák következtében továbbra is jelentősek. A levegőben található allergének okozta megbetegedések (szénanátha, asztma) idényjellegében és időtartamában is várhatóan változások következnek be. A környezetkárosodás hatásai az élelmiszer- és ivóvízellátásra, valamint a tengerszint emelkedése okozta kényszerű migráció az egészségügyi rendszerek kapacitás növelésének igényét eredményezheti, kiegészítve a már előbb említett újkori menekülthullám okozta problémákkal. [4]

A fentiek elemzése alapján egyértelmű, hogy elengedhetetlen mindent megtenniannak érdekében, hogy Földünk környezetterhelése a lehető legalacsonyabb legyen, hiszen a klímaváltozás hatással van egészségi állapotunkra, ezáltal pedig az egészségügyi rendszerre is. Így a fenntartható környezet sokkal inkább létkérdésünk, mint azt egy évtizeddel korábban gondoltuk.

Hans Bruyninckx szerint a probléma kezelése nagyon összetett, de az világos, hogy hosszú távú megoldást a kulcsfontosságú rendszerek, mint például az energia-, a közlekedés, vagy éppen az élelmezés átalakítása jelentheti. Alapvetően fontos, hogy szén-dioxid-mentesítésük által ezek alapvetően fenntarthatóak legyenek, hogy sokkal hatékonyabbakká váljanak az erőforrások 
tekintetében, és összhangba kerüljenek az ökoszisztémák ellenálló képességével. De újra kell tervezni az ezeket irányító rendszereket is, úgy, mint az adórendszert, a pénzügyet, az egészségügyet, az oktatást, vagy a jogot. [9]

Az Európai Unió megalkotta környezetvédelmi stratégiáját és a 2050-re meghatározott célok elérése érdekében három kulcsfontosságú területre összpontosítja intézkedéseit:

- a gazdasági felvirágzást és emberi jóllétet támogató természeti tőke védelme;

- az erőforrások terén hatékony, alacsony szén-dioxid-kibocsátású gazdasági és társadalmi fejlődés ösztönzése;

- az emberek környezeti egészségi kockázatoktól való védelme. [9]

A jó hír az, hogy van remény arra, hogy ezen innovatív stratégia konzekvens végrehajtásával nem csak pénzt szabadít fel az intézkedések sorozata az ágazatban, hanem javítja egyénileg és populációs szinten is az egészségi állapotot.

\subsection{Humán erőforrás hiány}

Az egyik legnehezebb kihívás az egészségügyi humán erőforrás hiány megoldása az ágazatban a kontinensen.

A munkaerőhiány egyik oka, hogy az állam, illetve a munkáltatók az egészségügyben a költségvetési stabilitás érdekében a leggyorsabban eredményt produkáló megszorító intézkedéseket választják (azaz a munkaerőn spórolnak) és korlátozzák a távozó alkalmazottak utánpótlását, a szükséges új munkaerő felvételét, illetve nem tesznek hatékony lépéseket a meglévőmunkaerő megtartása érdekében. [15]

Az előrejelzések alapján a becsült hiány olyan méretű, amelyet az egészségügyi szakemberek Unión belüli átrendeződése sem fog tudni egyetlen tagállamot sem mentesíteni a probléma alól.Jól példázzaezt egy 74 német kórházat felölelő kérdőíves kutatás eredménye is, mivel a megkérdezettek többsége a legnagyobb valószínűséggel előforduló jövőbeni krízishelyzetként tartja számon a szakképzett munkaerő hiányát. [17] Európa egésze érdekelt a munkaerőhiányból eredő problémák kezelésében, nem csak az Unió gazdasági, pénzügyi nehézségekkel küzdő országaiban megjelenő problémáról beszélhetünk.

Az unióban az egészségügyi dolgozókkal foglalkozó cselekvési terv 2012-es megalkotása is alátámasztja, hogy összehangolt lépéseket szükséges tenni a tendencia megállítása, illetve megfordítása érdekében.A cselekvési terv által vázolt megoldások között meghatározásra került a munkaerő tervezés ciklusa (6. ábra), amelyet a humán erőforrás krízis megakadályozása érdekében javasolt lenne szem előtt tartania a tagországoknak az ágazatban, hiszen stratégiai tervezés nélkül a hiány nem lesz orvosolható. 


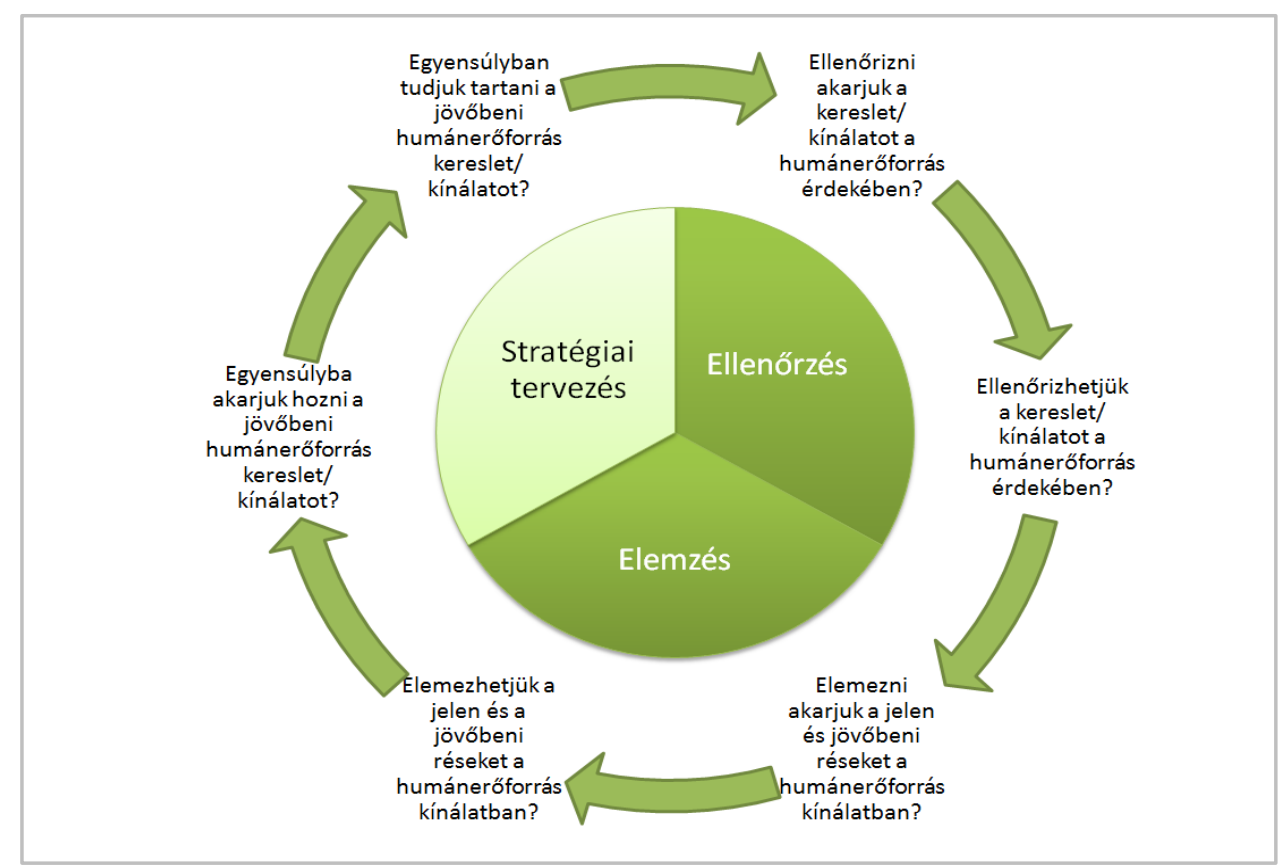

6. ábra: Munkaerő tervezés ciklusa

(Forrás:A FeasibilityStudyon EU levelCollaborationonForecasting Health WorkforceNeeds, WorkforcePlanning and Health WorkforceTrends, 2012)

Meg kell jegyezni, hogy a felvázolt probléma (is) túlmutat az Európai Unión és egy globális kihívásról beszélhetünk, hiszen a 2013-ban Brazíliában megtartott 3. Világ Egészségügyi Humánerőforrás Fórum ún. Recifei Nyilatkozatában is már megfogalmazásra került, hogy a munkaerőhiány okozta problémák csökkentése szükséges. Reformlépésekre is javaslatot tettek, többek között az egészségügyi humánerőforrás teljesítményének növelésére innovatív, hatékony és célzott menedzseri eszközök, megközelítések és ösztönzők nyújtotta megoldásokkal. [13]

Egy olyan elkövetkezendő jövőben ahol a társadalom elöregedő, a technológiai fejlődésnek semmi sem szabhat határt, kell majd egy megfizethető és fenntartható egészségügyi rendszert múködtetni, melynek új iránya már a betegközpontúság kell, hogy legyen az információtechnikával felvértezett fogyasztói társadalomban. Ez pedig egészségügyi szakszemélyzet nélkül nem megy. Sürgető problémáról beszélhetünk, hiszen a már jelentkező humán erőforrás deficit megmutatja, hogy az elmúlt időszakban is hiányzott a megfelelő támogatás, valamint a megfelelő menedzsment, hiszen „a menedzsment minősége és vezetői képessége, amellyel az alkalmazottak szembesülnek, alapvető fontosságú a munkaerő-megtartás szempontjából”. [8] Ez a jövő egészségügyének legsúlyosabb kihívása, aminek a megoldása közös erőfeszítéseket igényel.

\section{Összefoglalás}

Az áttekintésben felvázolt kihívások fel kell, hogy hívják a modern kor társadalmának figyelmét arra, hogy ezeknek a problémáknak a kezelése sokkal inkább létkérdésünk, mint azt valaha gondoltuk volna. Ezeknek mindegyike önmagában is számos kérdést vet fel és új megoldandó nehézségeket okoz az egészségügyi ágazat számára, azonban a vizsgálat azt is megmutatta, hogy a legsúlyosabb gondokat 
a humánerőforrás problémák generálhatják, hiszen mindegyik feladat megoldásában kulcsfontosságú szerep jut az embereknek, akik az ágazatban dolgoznak. Így a legsürgetőbb és egyben legnehezebb kihívás az egészségügyi humán erőforrás hiány megoldása az egészségügyben a kontinensen. Az Európai Bizottság előrejelzése szerint mintegy 1 millió szakember fog hiányozni 2020-ra az ágazatból, melynek összetétele becslések szerint a következő: 230000 orvos, 150000 fogorvos, valamint 590000 nővér.Amennyiben kiegészítjük ezt az előrejelzést azzal az információval, hogy ezen szakember hiány következtében az egészségügyben a jelenleg szükséges ellátási igények tizenöt százaléka ellátás nélkül maradhat, a probléma súlya megkérdőjelezhetetlen. [7] Ehhez adódik még a fenti kihívások kezeléséből adódó többlet humánerőforrás igény az ágazatban. A munkaerőhiány oka összetett, de az okok feltárása és azok kezelése elengedhetetlen.

Az egészségügyi munkaerő-tervezés lesz az egyik legnagyobb kihívás az egészségpolitikusok és a politikai döntéshozók számára egész Európában az elkövetkező évtizedekben. Ahhoz, hogy hatékony lépésekre kerüljön sor, politikai elkötelezettséggel párosuló összehangolt intézkedésekre van szükség uniós, tagállami és intézményi szinten. Az idő pedig sürget, mert a korábbi keresletnövekedés mellett az új kihívások is tovább feszítik az ágazat tűrőképességét.

\section{Hivatkozások}

[1] N. Barr, A jóléti állam gazdaságtana, Akadémiai Kiadó, Budapest, 404-406.

[2] K. Bíró (2011), A magyar egészségügyi ellátórendszer működtetésének kihívásai, Doktori /PhD/Értekezés, 70.

[3] K. Bíró, J. Zsuga, J. Kormos, R. Ádány (2011), The effect of financingontheallocation and productionefficiency of theHungarianhealthcaresystem Society and Economy

[4] Bizottsági szolgálati munkadokumentum - Fehér Könyv (2009), Az éghajlatváltozás hatása az emberek, az állatok és a növények egészségére, Brüsszel

[5] P. Brzoska, U. Ellert, A. Kimil, O. Razum, A-C. Sass, R. Salman, H. Zeeb (2015), Reviewing the topic of migration and health as a new national health target for Germany, Int J Public Health, 60:13-20.

[6] Centers for Disease Control and Prevention http://www.cdc.gov/climateandhealth/effects/ (letöltés: 2016. január 29.)

[7] Commission feasibility study on EU level collaboration on forecasting health workforce needs, workforce planning and health workforce trends, 2012

[8] Európai Egészségügyi Menedzsment Társaság (2015), Az egészségügyi munkaerő toborzása és megtartása Európában, Európai Bizottság, B-1049, Brüsszel, 10.

[9] Európai Környezetvédelmi Ügynökség (2015), Az Európai környezet állapot és előretekintés, Összefoglaló Jelentés

[10] Eurostat (2016), Greenhousegasemission, http://ec.europa.eu/eurostat (letöltés: 2016. január 26.) 
[11] FOCUS on Health Spending @ OECD Health Statistics 2015, http://www.oecd.org/health/health-systems/Focus-Health-Spending-2015.pdf (letöltés: 2016. január 28.)

[12] J. A. M. Gray (2011), How To Get Better Value Healthcare, Oxford Press

[13] Human resources for health (2013), foundation for universal health coverage and the post2015 development agenda: report of theThird Global Forum on Human Resources for Health, 10-13 November 2013, Recife, Brazil

[14] A. Kentikelenis, M. Karanikolos, G. Williams, P. Mladovsky, L. King, A. Pharris, J. E. Suk, A. Hatzakis, M. McKee, T. Noori, D. Stuckler (2015), How do economic crises affect migrants' risk of infectious disease? A systematic-narrative review, The European Journal of Public Health

[15] M. Kroezen, G. Dussault, I. Craveiro, M. Dieleman, C. Jansen, J. Buchan, et al. (2015), Recruitment and retention of health professionals across Europe: A literature review and multiplecase study research, Health Policy, 119, 1517-1528.

[16] R. A. Prentice Law, Gratuitous Promises (2007), University of Illinois Law Review, 2007:3 881-938.

[17] C. C. Schermuly, M. Draheim, R. Glasberg, V. Stantchev, G. Tamm, M. Hartmann, F. Hessel (2015), Human resource crises in German hospitals-an explorative study, Human Resources for Health, 13:40.

[18] E. H. Showalter (1997), Hysterical Epidemics and Modern Culture, Columbia University Press

[19] WHO: Emergenciespreparadness, response, http://www.who.int/csr/don/archive/year/2014 (letöltés: 2015. augusztus 14.)

[20] WHO: Zikavirus fact sheet, http://www.who.int/mediacentre/factsheets/zika/en/ (letöltés: 2016 március 2. 